\title{
PENGARUH PENGGUNAAN SUKROSA DAN PENSTABIL KARBOKSI METIL SELULOSA (CMC) TERHADAP MUTU DAN GINGEROL JAHE INSTAN
}

\section{The Use Effect of Sucrose and Stabilizer Carboxy Methyl Cellulose (CMC) on The Quality and Gingerol of Instant Ginger}

Firdausni*, Wilsa Hermianti, dan Robby Kumar

Balai Riset dan Standardisasi Industri Padang

JI. Raya LIK No.23 Ulu Gadut Padang, Indonesia

*e-mail firdausni85@gmail.com

Diterima: 22 September 2017, revisi akhir: 17 Desember 2017 dan disetujui untuk diterbitkan: 22 Desember 2017

\section{ABSTRAK}

Jahe mengandung gingerol yang sangat bermanfaat dalam industri farmasi dan makanan. Gingerol memiliki kemampuan sebagai antioksidan dan antiinflamasi. Pengolahan jahe menjadi jahe instan akan memudahkan dalam penyajian dan stabilitas ketersediaan jahe. Penelitian bertujuan untuk mendapatkan teknologi proses dan pembuatan produk jahe instan dengan mutu baik serta kandungan gingerol yang tinggi. Penelitian dilakukan dengan perlakuan variasi penambahan sukrosa yaitu gula pasir $100 \%$, perbandingan gula pasir dan gula aren (3:1) dan (1:1), serta penambahan penstabil karboksimetil selulosa (CMC), yaitu kontrol, $0,5 \%$, dan $1 \%$. Hasil penelitian menunjukkan bahwa penambahan variasi gula sebagai sumber sukrosa dan penambahan penstabil CMC dapat mempengaruhi mutu produk. Perlakuan pemakaian gula pasir : gula aren (3:1) dan penambahan penstabil CMC $1 \%$ memberikan hasil optimal dengan kadar air 1,54\%, kadar abu $0,73 \%$, kadar gula $76 \%$, total padatan terlarut $97,01 \%$, total asam $0,16 \%$, serta analisis $6,8,10$ gingerol berturut turut, yaitu $1,240 \mathrm{mg} / \mathrm{g} ; 0,045 \mathrm{mg} / \mathrm{g} ; 0,070 \mathrm{mg} / \mathrm{g}$; dan 6 shogaol $0,175 \mathrm{mg} / \mathrm{g}$.

Kata kunci: jahe, penstabil, gingerol, jahe instan, CMC

\section{ABSTRACT}

Ginger contains gingerol which is very useful in the pharmaceutical and food industries. Gingerol has an ability as an antioxidant and anti-inflammatory. Processing of ginger into instant ginger can make it easy in presentation and the stability of ginger availability. The research was aimed to get the technology and manufacturing process of instant ginger products with good quality and a high content of gingerol. The study was conducted with the treatment of sucrose addition $100 \%$ granulated sugar, the ratio of granulated sugar and palm sugar (3:1) and (1:1), and the addition of stabilizer carboxy methyl cellulose (CMC) namely control (0\%), $0.5 \%$, and $1 \%$. The results showed that the addition of sugar as a source of sucrose and the addition of stabilizers CMC could affect the product quality. The treatment of granulated sugar and palm sugar ration (3:1) and the addition of stabilizers CMC $1 \%$ produced an optimum result with water content $1.54 \%$, ash content $0.73 \%$, sugar content $76 \%$, total dissolved solids $97,01 \%$, total acid $0.16 \%$, as well as analysis of 6,8,10 gingerol was $1.240 \mathrm{mg} \mathrm{g}^{-1} ; 0.045 \mathrm{mg} \mathrm{g}^{-1} ; 0.070 \mathrm{mg} \mathrm{g}^{-1}$ respectively and 6 shogaol $0.175 \mathrm{mg} \mathrm{g}^{-1}$.

\section{Keywords: ginger, stabilizers, gingerol, instant ginger, CMC}

\section{PENDAHULUAN}

Indonesia memiliki sumber kekayaan alam yang berlimpah, termasuk jenis tanaman-tanaman herbal, diantaranya diketahui manfaatnya bagi kesehatan (Srinivasan, 2017). Pengolahan tanaman herbal menjadi minuman fungsional memerlukan pengetahuan tentang kandungan senyawa aktif (Ibrahim et al., 2015)

Jahe (Zingiber officinale.) merupakan salah satu tanaman komersial yang memiliki banyak manfaat, digunakan 
sebagai rempah-rempah, bumbu masak, dan sebagai penambah rasa. Rimpang jahe memiliki beberapa kegunaan dalam pengobatan tradisional, antara lain obat sakit kepala, masuk angin, dan menambah nafsu makan (Stimulansia) (Srinivasan, 2017). Jahe memiliki kandungan antioksidan yakni oleoresin yang lebih dikenal sebagai gingerol. Jahe dimanfaatkan sebagai minuman fungsional dengan pewarna casiavera (Firdausni et al., 2011)

Hasil olahan jahe pada makanan dan minuman ditemukan pada manisan jahe, wedang jahe, sekoteng (sejenis minuman), wedang kopi jahe dan sebagainya. Senyawa antioksidan dalam bumbu dan rempah pada jahe, yaitu Shogaol dan gingerol (Embuscado, 2015).

Jahe mengandung sekurangnya 19 komponen bioaktif yang berguna bagi tubuh. Komponen utama adalah gingerol yang bersifat antikoagulan, yaitu mencegah pengumpalan darah dan melancarkan aliran darah sehingga dapat mencegah penyakit stroke, jantung dan penyakit degeneratif lainnya (Stoilova et al., 2007).

Perkembangan ilmu pengetahuan tentang produk pangan yang memadukan antara fungsi nutrisi dan kesehatan yang sering disebut pangan fungsional. Pangan fungsional merupakan produk pangan yang memberikan keuntungan terhadap kesehatan (Khan et al., 2013).

Oleoresin merupakan salah satu senyawa non volatil yang mengandung minyak atsiri 15\%-35\% yang diekstraksi dari bubuk jahe. Semakin tinggi kandungan oleoresin maka makin pedas rasa ekstrak jahe yang dihasilkan dan makin tinggi efek antioksidannya (Stoilova et al., 2007).

Sifat khas pedas jahe berasal dari senyawa kimia jahe seperti zingeron, shogaol, dan gingerol sedangkan konstituen flavor dari minyak atsiri seperti sineol, borneol, geraniol, linalool, dan farmasen yang memberikan aroma khas pada jahe). Oleoresin jahe mengandung komponen flavor yang memberikan rasa pedas (pungent) jahe. Dua komponen utama yang memberikan pungent jahe adalah gingerol dan shogaol. Kandungan gingerol dalam oleoresin antara 14\%-25\% dan shogaol dalam oleoresin antara 2,8\%-
7,0\% (Shobana and Akhilender Naidu, 2000; Srinivasan, 2017; Zick et al., 2008).

Jahe instan cepat larut dalam air pada suhu rendah maupun panas sehingga mudah dalam penyediaan sebagai minuman fungsional. Penelitian ini bertujuan untuk menghasilkan olahan jahe instan yang siap saji dan dapat ditambahkan pada makanan dan minuman. Penambahan penstabil seperti CMC diharapkan akan memperbaiki mutu produk.

Tujuan penambahan sukrosa dan penstabil CMC yakni untuk meningkatkan mutu dan memudahkan penyimpanan jahe sehingga khasiat fungsionalnya untuk kesehatan dapat terjaga dengan baik.

\section{METODOLOGI PENELITIAN}

Bahan proses yang diperlukan adalah jahe segar yang diperoleh dari Pasar Raya Padang sebagai bahan utama, gula pasir, gula aren, bumbu (cengkeh, kayu manis, kayu secang). Bahan kimia untuk analisis, yaitu aquades, etanol $96 \%$, larutan reagen follin ciocalteu, $\mathrm{Na}_{2} \mathrm{CO}_{3}$, iodium, amilum, indikator phenolphtalein, $\mathrm{H}_{2} \mathrm{SO}_{4}, 1,1$ Diphenyl-2-Picrylhyrazyl (DPPH).

Alat yang digunakan adalah timbangan analitik, crusher (penghancur), kain saring, erlenmeyer, gelas ukur, hot plate, termometer. Alat yang digunakan untuk analisis, yaitu inkubator, HPLC, oven, petri dish, spektrofotometer UV.

\section{Pelaksanaan Penelitian}

Jahe instan merupakan jahe serbuk yang siap saji dan pembuatannya melalui beberapa tahapan.

1. Sortasi atau pemilihan

Sortasi dilakukan dengan memilih jahe dengan kualitas baik dan memisahkan dari bahan asing.

2. Pencucian

Pembersihan jahe dengan air bersih atau air mengalir agar terbebas dari kuman yang menyebabkan kontaminasi.

3. Pemotongan

Jahe dipotong-potong untuk memudahkan dalam menghaluskan jahe. 
4. Penghancuran

Setelah pemotongan dilanjutkan dengan penghancuran melalui penambahan air $(500 \mathrm{ml}$ air untuk $1 \mathrm{~kg}$ jahe) agar memudahkan penghancuran sehingga dihasilkan bubur jahe.

5. Penyaringan

Bubur disaring dengan kain saring dan didapatkan ekstrak berupa sari jahe. Penyaringan dimaksudkan untuk memisahkan sari jahe dengan ampas.

6. Presipitasi .

Pengendapan sari jahe dengan mendiamkan selama 30 menit sehingga pati jahe menyendap.

7. Pemasakan

Sari jahe yang telah dipisahkan dari pati dipanaskan dan dilakukan pengadukan secara terus menerus dengan pemanasan sedang (suhu 80$100^{\circ} \mathrm{C}$ ). Setelah volume sari jahe telah berkurang sebanyak seperempat larutan awal maka ditambahkan sukrosa, bahan tambahan lainnya, yaitu kayu secang, cengkeh, kayu manis, dan CMC.

8. Pengkristalan

Pengadukan terus dilakukan sehingga larutan jenuh dan terbentuk kristalkristal warna kecoklatan. Pemanasan dihentikan dan pengadukan tetap dilakukan agar diperoleh ukuran serbuk yang seragam.

9. Pengayakan

Jahe serbuk yang dihasilkan kemudian disaring dengan ayakan 80 mesh agar ukurannya seragam dan mudah larut dalam penyajiannya.

10. Pengemasan dan pelabelan

Pengemasan dan pelabelan jahe instan dilakukan dengan kemasan plastik yang tertutup rapat.

\section{Rancangan Penelitian}

Rancangan penelitian yang dilakukan berupa Rancangan Acak Lengkap (RAL) dengan perlakuan perbandingan pemakaian jenis gula $(A)$, yaitu $A 1$ : gula pasir $100 \%$, A2: gula pasir :gula aren (3:1), A3: gula pasir gula aren (1:1), dan $B$ konsentrasi penstabil CMC, yaitu $\mathrm{B} 1$ : kontrol (tanpa CMC), B2: CMC 0,5\% dan B3: CMC 1\% dengan 3 kali ulangan.

\section{Analisis Jahe Instan.}

Analisis yang dilakukan terhadap jahe instan meliputi sifat fisik, rendemen, kadar air, kadar abu, total asam, total padatan terlarut, kandungan gingerol dan shogaol. Uji organoleptik dilakukan dengan skala hedonik dengan skor 5 (sangat suka) 4 (suka), 3 (biasa), 2 (kurang suka) dan 1 (tidak suka) terhadap rasa, warna dan aroma jahe instan.

\section{HASIL DAN PEMBAHASAN}

Kadar air dan Abu Jahe Instan.

Jahe instan merupakan produk minuman berupa serbuk yang dapat langsung dikonsumsi sebagai minuman kesehatan. Minuman kesehatan merupakan minuman yang mengandung unsur-unsur zat gizi jika dikonsumsi dapat memberikan pengaruh positif terhadap kesehatan tubuh (Encik Eko and Martanto, 2016)

Minuman kesehatan yang sudah dikenal masyarakat dijumpai di pasaran dengan berbagai merek dan bentuk seperti dalam bentuk serbuk instan ataupun tablet. Kecenderungan masyarakat saat ini adalah lebih suka menggunakan produk yang kemasan dan penyajiannya lebih praktis dan cepat karena tidak membutuhkan banyak waktu dalam mempersiapkannya.

Pengolahan jahe instan dengan perlakuan jenis gula (sukrosa) dan penambahan pengemulsi CMC menghasilkan produk secara visual berbeda seperti warna dan tekstur seperti terlihat pada Tabel 1.

Pengolahan jahe segar menjadi jahe instan menghasilkan rendemen 63,50\%$69,50 \%$. Rendemen jahe instan berdasarkan penambahan sumber sukrosa, yaitu gula pasir dan gula aren, kemudian ditambahkan dengan jahe segar serta bahan lainnya.

Sukrosa bersifat sebagai pengikat dari ekstrak jahe melalui proses kristalisasi. Rendemen tertinggi dihasilkan pada pemakaian gula pasir: gula aren (1:1) dan penstabil CMC 1\% dan dihasilkan butiran lebih besar dibandingkan dengan pemakaian $100 \%$ gula pasir. Hal ini disebabkan gula aren mempunyai butiran 
yang lebih besar pada proses kristalisasi dan kadar air yang lebih tinggi sehingga bersifat lebih higroskopis dibandingkan dengan penggunaan gula pasir.

Karakteristik warna yang dihasilkan pada pemakaian gula aren akan menghasilkan warna yang lebih gelap (kecoklatan). Gula aren berasal dari nira pohon aren yang diproses secara alami dan sederhana tanpa proses pemutihan, sedangkan gula pasir berasal dari tebu dan tanaman umbi umbian dan diproses dengan pemurnian berulang dengan menggunakan bahan tambahan untuk memurnikannya. Karakteristik warna yang dihasilkan pada pemakaian gula aren akan menghasilkan warna yang lebih gelap (kecoklatan). Gula aren berasal dari nira pohon aren yang diproses secara alami dan sederhana tanpa proses pemutihan, sedangkan gula pasir berasal dari tebu dan tanaman umbi umbian dan diproses dengan pemurnian berulang dengan menggunakan bahan tambahan untuk memurnikannya.

Tabel 1. Rendemen dan karakteristik secara visual dan rendemen jahe instan hasilpenelitian

\begin{tabular}{|c|c|c|c|}
\hline No & Perlakuan & Rendemen (\%) & Karakteristik \\
\hline 1 & A1B1 & 63,50 & $\begin{array}{l}\text { - Kristal halus } \\
\text { - Warna putih kekuningan }\end{array}$ \\
\hline 2 & A1B2 & 64,00 & $\begin{array}{l}\text { - Kristal halus } \\
\text { - Warna putih kekuningan }\end{array}$ \\
\hline 3 & A1B3 & 65,00 & $\begin{array}{l}\text { - Kristal dengan butiran kasar } \\
\text { - Warna kecoklatan }\end{array}$ \\
\hline 4 & A2B1 & 65,00 & $\begin{array}{l}\text { - Kristal halus } \\
\text { - Warna putih kekuningan }\end{array}$ \\
\hline 5 & A2B2 & 68,00 & $\begin{array}{l}\text { - Kristal halus } \\
\text { - Warna putih kekuningan }\end{array}$ \\
\hline 6 & A2B3 & 68,50 & $\begin{array}{l}\text { - Kristal halus } \\
\text { - Warna putih ekuningan }\end{array}$ \\
\hline 7 & A3B1 & 68,00 & $\begin{array}{l}\text { - Kristal dengan butiran kasar } \\
\text { - Warna keecoklatan }\end{array}$ \\
\hline 8 & A3B2 & 69,50 & $\begin{array}{l}\text { - Kristal dengan butiran kasar } \\
\text { - Warna kecoklatan }\end{array}$ \\
\hline 9 & A3B3 & 65,00 & $\begin{array}{l}\text { - Kristal dengan butiran kasar } \\
\text { - Warna kecoklatan }\end{array}$ \\
\hline
\end{tabular}

Sumber: data hasil penelitian sendiri

\section{Kadar Air dan Kadar Abu}

Hasil analisis kadar air jahe instan pada perlakuan pemakaian sukrosa dan pemakaian penstabil CMC (Gambar 1). Kadar air terendah pada gula pasir $100 \%$ dan tanpa penstabil CMC, yaitu $0,48 \%$. Kadar air yang bervariasi 0,48\%-1,89\%, sedangkan kadar air menurut SNI 01-04302004 tentang persyaratan minuman serbuk tradisional adalah kadar air maksimal 3\%. Hal ini menunjukkan bahwa jahe instan pada pemakaian sukrosa dan penstabil CMC memenuhi syarat sesuai SNI.
Kadar air awal dalam bahan pangan ikut menentukan tingkat penerimaan konsumen, kesegaran, dan daya tahan dari makanan tersebut. Kadar air yang tinggi akan mempengaruhi mutu produk dan mengakibatkan mudah rusak dan sangat rentan dengan pengaruh faktor lingkungan, produk akan teroksidasi sehingga akan merubah komponen yang ada (Winarno, 2009).

Jahe instan merupakan minuman dalam bentuk bubuk atau serbuk cara pengkonsumsiannya lebih praktis karena berupa produk yang ready to drink yang 
dapat disajikan kapan pun dan dimana pun (Encik Eko and Martanto, 2016)

Produk minuman instan dibuat dengan proses kokristalisasi. Kokristalisasi merupakan salah satu teknik dalam mikroenkapsulasi. Mikroenkapsulasi sebagai aktivitas yang secara umum mirip dengan teknologi pengemasan, yaitu pengemasan zat padat, cair atau gas ke dalam suatu bentuk mikrokapsul (Permata and Sayuti, 2016).

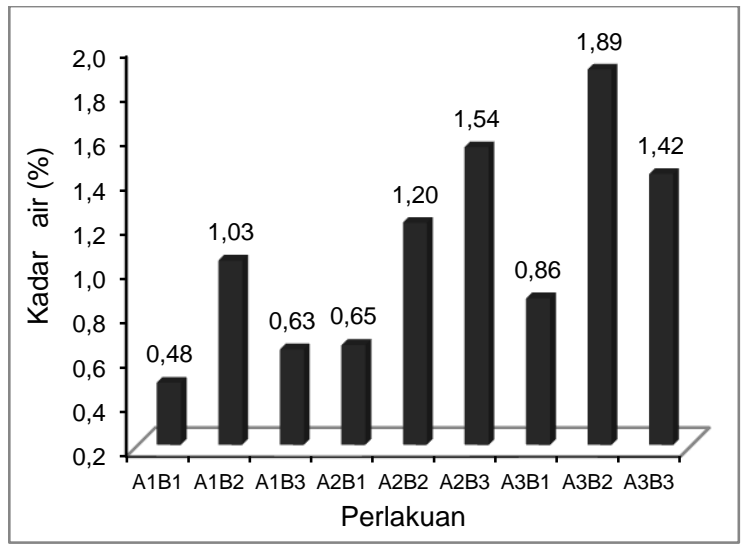

Gambar 1. Kadar air jahe instan pada perlakuan sumber sukrosa dan penambahan penstabil CMC.

Kadar air jahe instan dengan perlakuan pemakaian sukrosa gula aren lebih tinggi dari gula pasir. Gula pasir merupakan kristalisasi dari cairan tebu yang bewarna putih memiliki butir yang keras dan halus dengan kadar air yang rendah. Gula aren berasal dari nira batang aren berupa balok yang berwarna coklat, aromanya khas aren dan mempunyai kadar air yang lebih tinggi.

Pemakaian penstabil CMC tidak berpengaruh nyata terhadap kadar air. CMC dalam produk pangan berfungsi sebagai pengikat air dan pembentuk gel yang akan menghasilkan tekstur produk pangan. CMC berfungsi membentuk sistem dispersi koloid dan meningkatkan viskositas sehingga partikel-partikel yang tersuspensi akan tertangkap dalam sistem tersebut dan tidak mengendap oleh pengaruh gaya gravitasi (Kamal, 2010).

Kadar abu jahe instan hasil penelitian seperti terlihat pada Gambar 2, yaitu $0,48 \%-0,96 \%$. Abu adalah zat anorganik sisa hasil pembakaran suatu bahan organik.

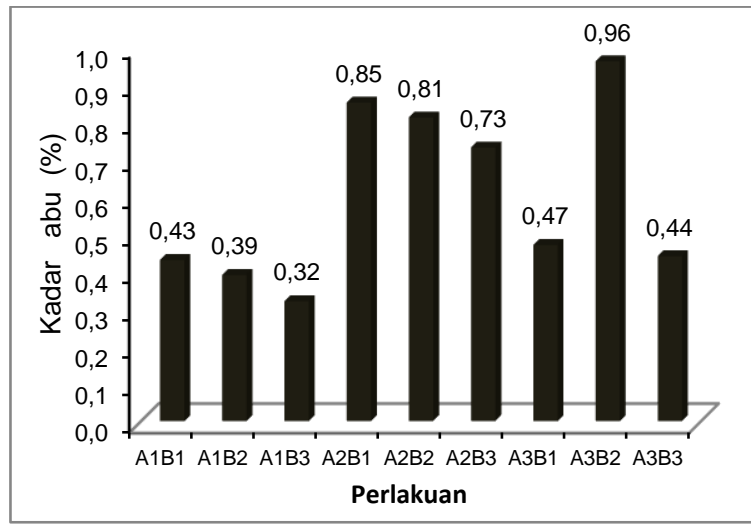

Gambar 2. Kadar abu jahe instan pada perlakuan sumber sukrosa dan penambahan penstabil CMC.

Kadar abu minimum terdapat pada pemakaian $100 \%$ gula pasir dan penambahan CMC 1\%. Kadar abu jahe instan dipengaruhi oleh jahe yang digunakan, penambahan bahan seperti gula pasir, gula aren, dan penambahan penstabil CMC. Kadar abu erat kaitannya dengan mineral yang dikandung oleh suatu bahan tersebut. Winarno (2004) menyatakan bahwa unsur mineral tersebut terdapat dalam bentuk organik, garam anorganik, atau sebagai bentuk senyawa kompleks yang bersifat organik dan penentuan kadar abu sering kali dilakukan untuk mengendalikan garam-garam anorganik seperti garam kalsium. Dalam proses pembakaran, bahan organik terbakar tetapi zat anorganiknya tidak, karena itulah disebut abu. Pemakaian gula pasir memberikan kadar abu yang lebih rendah dari pada gula aren.

\section{Kadar Gula}

Hasil analisis terhadap kadar gula jahe instan seperti terlihat pada Tabel 2, yaitu $72 \%-78 \%$. Perlakuan pemakaian sumber sukrosa gula pasir dan gula aren tidak berpengaruh nyata terhadap kadar gula jahe instan. Penambahan gula pada pembuatan instan jahe bubuk berfungsi sebagai pengikat ekstrak jahe, sehingga terbentuk kristal. Kristalisasi dalam produk pangan merupakan salah satu unsur 
pembentuk struktur dalam bahan atau produk pangan. Kadar gula yang tinggi dapat berfungsi sebagai pengawet sehingga daya simpan produk lebih lama. Penambahan CMC terhadap kadar gula jahe instan tidak berpengaruh terhadap kadar gula. CMC merupakan penstabil yang dapat meningkatkan homogenisasi dari minuman.

Tabel 2. Analisis rata-rata kadar gula jahe instan pada beberapa perlakuan.

\begin{tabular}{cc}
\hline Perlakuan & Rerata kadar gula (\%) \\
\hline A1B1 & 77,2 \\
A1B2 & 72,3 \\
A1B3 & 76,5 \\
A2B1 & 78,6 \\
A2B2 & 77,4 \\
A2B3 & 76,3 \\
A3B1 & 78,4 \\
A3B2 & 75,7 \\
A3B3 & 76,5 \\
\hline
\end{tabular}

Kadar gula yang tinggi dapat menghindarkan produk dari pertumbuhan mikroorganisme sehingga produk akan mempunyai masa simpan yang lebih lama.

\section{Total Padatan Terlarut}

Hasil analisis total padatan terlarut seperti pada Gambar 3. Total padatan terlarut jahe instan 95,2\%-97,9\%. Meningkatnya penambahan CMC menyebabkan total padatan terlarut jahe instan meningkat. Penambahan CMC sebanyak $1 \%$ menghasilkan total padatan terlarut paling tinggi $97,85 \%$ pada pemakaian gula pasir : gula aren (1:1).

Total padatan terlarut dalam pembuatan minuman mempunyai peranan yang sangat penting, dimana fungsinya untuk membentuk tekstur dan flavor pada produk yang dihasilkan. Total padatan terlarut dipengaruhi oleh komposisi bahan baku yang digunakan seperti sumber sukrosa, penstabil CMC dan lainnya. Padatan terlarut yang rendah menyebabkan produk akan tampak kasar dan teksturnya kurang homogen. Total padatan terlarut merupakan komponenkomponen kimia (lemak, protein, karbohidrat, mineral, vitamin) yang terkandung dalam bahan pangan setelah kandungan air diuapkan (Ismawati et al., 2016).

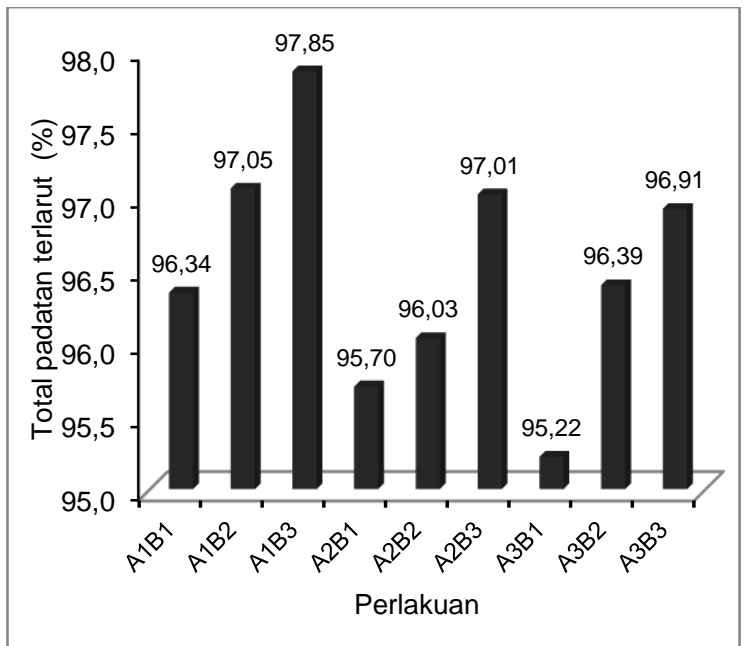

Gambar 3. Total padatan terlarut jahe instan pada perlakuan sumber sukrosa dan penambahan penstabil CMC

\section{Komponen Bioaktif Jahe Instan Gingerol dan Shogaol}

Komponen yang bertanggung jawab atas karakteristik jahe yang pedas dan tajam yaitu gingerol, gingerdiol dan shogaol membentuk oleoresin sebanyak $8 \%$ (Bustan et al., 2008). Rasa pedas pada jahe diakibatkan adanya senyawa gingerol (Chrubasik et al., 2005). Senyawa aktif yang terkandung dalam jahe seperti gingerol, shogaol memiliki sifat sebagai anti inflamasi, antioksidan, antibakteri, dan antitrombosit. Kandungan gingerol dan shogaol jahe instan pada beberapa perlakuan seperti terlihat pada Tabel 3.

Pemakaian gula aren $50 \%$ dan penambahan CMC $1 \%$ menunjukkan kandungan (6)-, (8)-, (10)-gingerol dan (6)shogaol lebih tinggi dari perlakuan lainnya, yaitu $0,240 \mathrm{mg} / \mathrm{g} ; 0,045 \mathrm{mg} / \mathrm{g} ; 0,070 \mathrm{mg} / \mathrm{g}$ dan $0,175 \mathrm{mg} / \mathrm{g}$. Pemberian CMC $1 \%$ dengan hasil optimal dengan gingerol yang lebih tinggi dari lainnya. Senyawa gingerol dan shogaol merupakan senyawa cita rasa yang memberikan atribut sensori pungent (pedas) pada jahe (Srinivasan, 2017). 
Tabel 3. Hasil analisis terhadap gingerol jahe instan pada perlakuan sumber sukrosa dan penambahan penstabil CMC

\begin{tabular}{cccccc}
\hline No & Perlakuan & $\begin{array}{c}6 \text { Gingerol } \\
(\mathrm{mg} / \mathrm{g})\end{array}$ & $\begin{array}{c}8 \text { Gingerol } \\
(\mathrm{mg} / \mathrm{g})\end{array}$ & $\begin{array}{c}10 \text { Gingerol } \\
(\mathrm{mg} / \mathrm{g})\end{array}$ & $\begin{array}{c}6 \text { Shogaol } \\
(\mathrm{mg} / \mathrm{g})\end{array}$ \\
\hline 1 & A1B1 & 0,186 & 0,034 & 0,106 & 0,053 \\
2 & A1B2 & 0,206 & 0,127 & 0,158 & 0,106 \\
3 & A1B3 & 0,151 & 0,037 & 0,041 & 0,059 \\
4 & A2B1 & 0,150 & 0,028 & 0,465 & 0,056 \\
5 & A2B2 & 0,206 & 0,127 & 0,158 & 0,106 \\
6 & A2B3 & 0,240 & 0,045 & 0,070 & 0,175 \\
7 & A3B1 & 0,163 & 0,031 & 0,187 & 0,049 \\
8 & A3B2 & 0,210 & 0,113 & 0,158 & 0,108 \\
9 & A3B3 & 0,143 & 0,087 & 0,054 & 0,062 \\
\hline
\end{tabular}

Konsentrasi senyawa 6-gingerol $(0,143-0,240 \mathrm{mg} / \mathrm{g})$ dan tertinggi pada perlakuan penambahan gula aren (1:1) dan CMC $1 \%$, yaitu $0,240 \mathrm{mg} / \mathrm{g}$. Penggunaan CMC $1 \%$ merupakan perlakuan yang optimal sehingga dihasilkan kestabilan sehingga kandungan gingerol tinggi.

Komponen bioaktif yang terdapat pada ekstrak jahe antara lain gingerol, shogaol, paradol dan yang lainnya yang bersifat termostabil. Komponen fenolik ini bertanggung jawab terhadap flavor jahe. Kadar gingerol jahe juga meningkat seiring dengan bertambahnya usia panen rimpang jahe (Chrubasik et al., 2005). Selama proses pengolahan jahe seperti pengeringan dan penyimpanan akan mengubah gingerol menjadi shogaol.

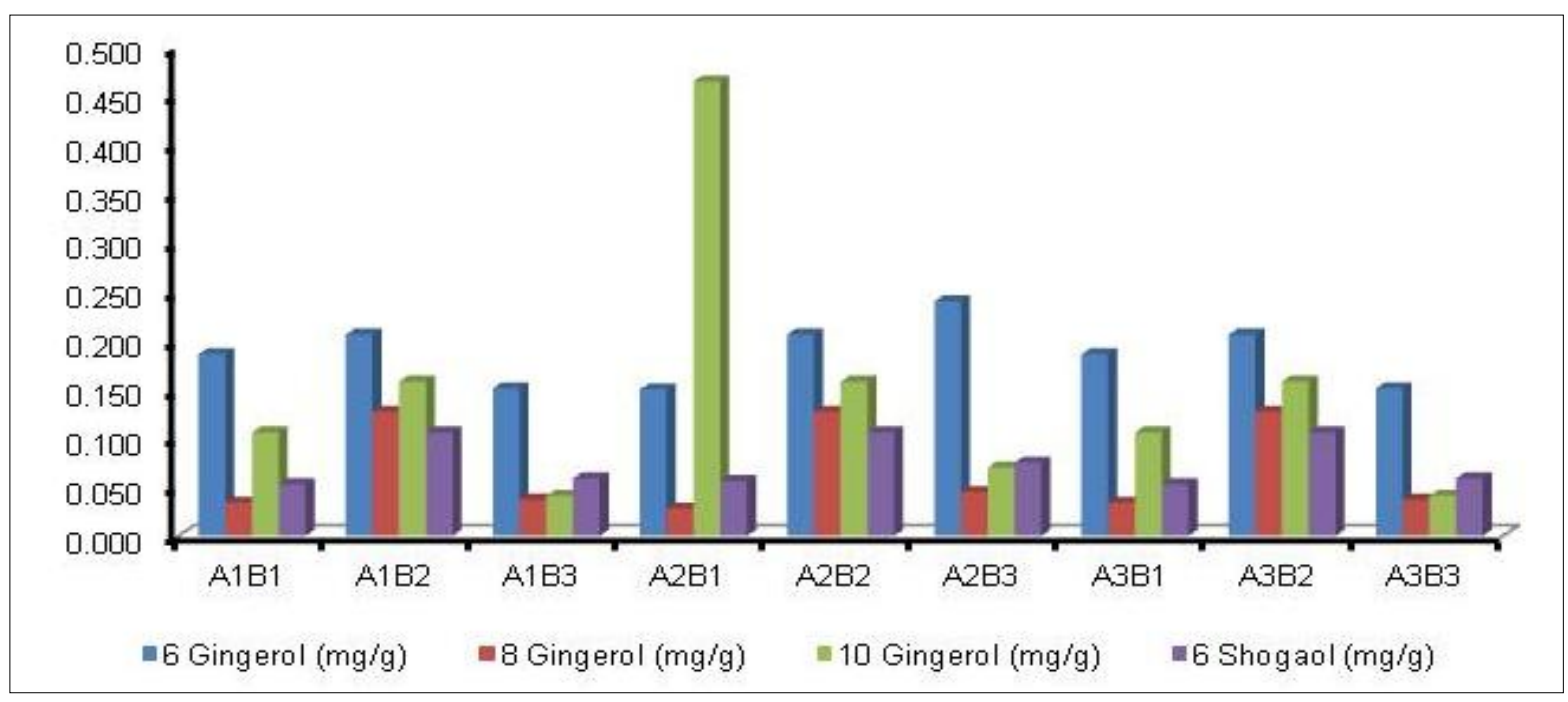

Gambar 4. Konsentrasi senyawa aktif 6, 8 dan 10 gingerol dan 6 Shogaol pada jahe instan dengan perlakuan sumber sukrosa dan penambahan penstabil CMC.

\section{Uji Organoleptik}

Hasil uji organoleptik panelis terhadap aroma, warna, rasa dan kelarutan terhadap jahe instan hasil penelitian dengan penilaian tingkat kesukaan (skala hedonik) mulai dari tidak suka sampai sangat suka 1-5 (sangat suka, suka, biasa, kurang suka dan tidak suka). Uji organoleptik jahe instan seperti terlihat pada Gambar 5. 


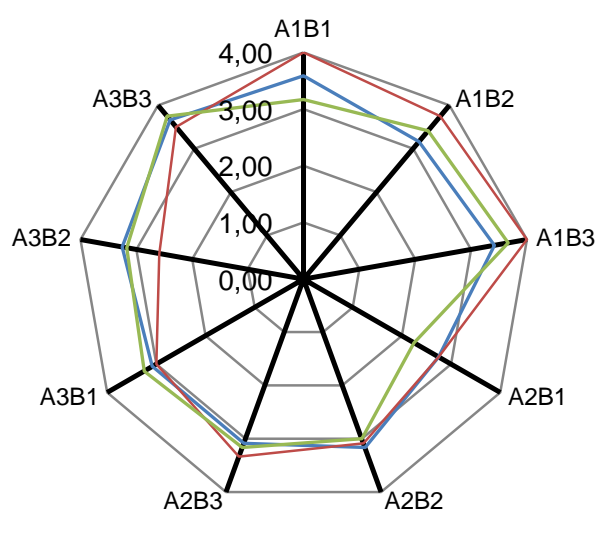

Aroma - Warna rasa

Gambar 5. Nilai rata-rata hasil uji organoleptik terhadap aroma, warna, rasa jahe instan pada perlakuan pemakaian sukrosa dan penambahan penstabil CMC.

\section{Aroma}

Hasil pengamatan terhadap aroma jahe instan pada perlakuan menunjukkan pemakaian sumber sukrosa memberikan nilai aroma yang berbeda, dimana dengan variasi pemakaian gula pasir dan gula aren memberikan perbedaan tingkat kesukaan terhadap aroma.

Penilaian terhadap aroma berkisar 2,75-3,67, dengan aroma tertinggi pada perlakuan pemakaian gula pasir dan gula aren (1:1) atau gula aren $50 \%$ dengan penambahan CMC $10 \mathrm{~g}$ (A3B3). Hal ini disebabkan karena gula aren mempunyai aroma yang khas dan disukai panelis, ditambah lagi dengan penggunaan jahe. Aroma merupakan faktor penting dalam produk pangan dan daya tarik produk sehingga dapat menimbulkan keinginan untuk mengkonsumsinya.

\section{Warna}

Hasil penelitian terhadap warna jahe instan seperti terlihat pada Gambar 5. Penilaian terhadap organoleptik warna 2,80-4,00 (disukai sampai sangat disukai). Penambahan penstabil CMC meningkatkan tingkat kesukaan terhadap warna jahe

instan, dimana makin tinggi penambahan CMC maka penilaian warna makin tinggi pula. Warna jahe instan dipengaruhi oleh bahan baku, proses dan suhu pengolahan selama pengolahan dan pemberian bahan tambahan.

Hasil penelitian ini menunjukkan pembuatan jahe instan melalui pemanasan dan homogenisasi dengan bahan baku utama jahe dan gula. Pembentukan kristalisasi gula sangat tergantung pada suhu pemanasan. Suhu yang tinggi akan menyebabkan produk berwarna gelap, sedangkan suhu yang rendah dapat menyebabkan kristalisasi kurang sempurna. Penggunaan suhu yang tepat akan menghasilkan warna yang diinginkan. Penggunaan penstabil CMC membuat tingkat penilaian terhadap warna jahe instan lebih disukai dari pada kontrol (tanpa $\mathrm{CMC})$.

\section{Rasa}

Hasil organoleptik panelis terhadap rasa jahe instan dengan nilai rata-rata 2,753,75 (disukai). Rasa yang dihasilkan jahe instan terbentuk dari bahan baku jahe, sumber sukrosa yang digunakan dan bahan tambahan, serta proses pemasakan. Kristal gula yang terbentuk akibat perubahan dari cairan menjadi serbuk padat. Pemanasan dan pengadukan yang tepat akan menghasilkan kristal kristal gula dan jahe dengan kualitas baik (Gambar 5), terlihat pemakaian gula pasir dan gula aren (1:1) atau $50 \%$ gula aren dengan penambahan penstabil CMC sebanyak $1 \%$ $(10 \mathrm{~g})$.

Berdasarkan hal di atas ternyata dengan penambahan $50 \%$ gula aren memberikan nilai terhadap rasa yang lebih tinggi. Keunggulan gula aren dibanding dengan gula lainnya yaitu tingginya kandungan sukrosa (84\%), protein 2,28\% kalsium 1,35\%, dan posfor 1,37\% (Abdussamad, 2014).

\section{Kelarutan}

Penilaian terhadap nilai kelarutan (Gambar 6), terlihat tidak berpengaruh nyata. Kelarutan tertinggi pada perlakuan penambahan gula pasir gula aren (1:1) dengan penambahan CMC $0,5 \%$. Hal ini menunjukkan bahwa dengan penggunaan pemakaian CMC $0,5 \%$ merupakan perlakuan yang terbaik. Kelarutan erat kaitannya dengan ukuran partikel. Semakin 
kecil ukuran partikel semakin tinggi kelarutannya. Kelarutan juga berhubungan dengan suhu pelarut yang kita gunakan. Suhu yang tinggi dapat meningkatkan kelarutan produk. Kelarutan jahe instan pada suhu $70^{\circ} \mathrm{C}$ menunjukkan nilai terhadap kelarutan tertinggi pada perlakuan pemakaian gula aren $50 \%$ dan CMC $0,5 \%$, yaitu 3,83 (disukai).

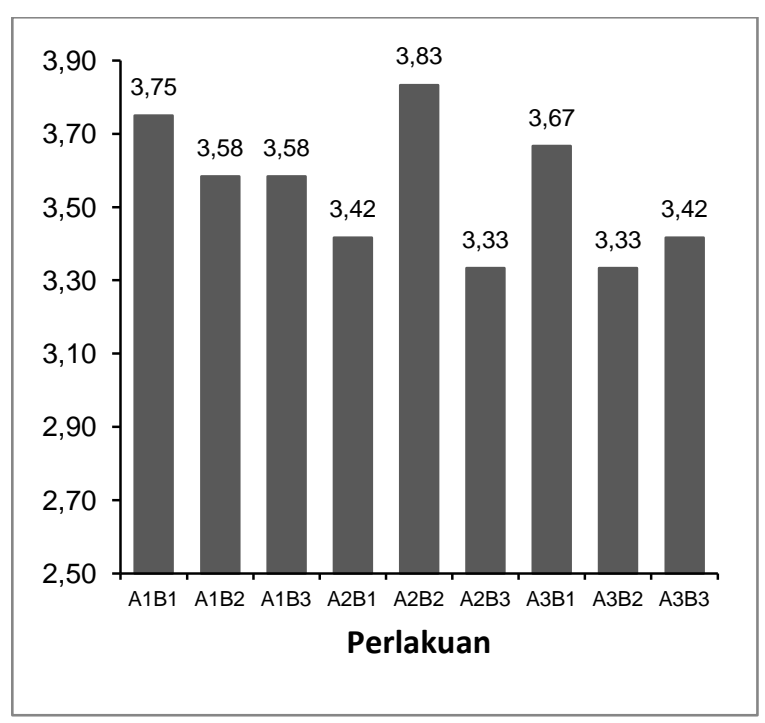

Gambar 6. Nilai rata-rata hasil uji organoleptik terhadap kelarutan jahe instan

\section{KESIMPULAN}

Penambahan sukrosa dan CMC sebagai penstabil dapat mempengaruhi kandungan proksimat (kadar air, abu, gula, total padatan terlarut), organoleptik dan kandungan bioaktif gingerol, shogaol dari jahe instan. Substitusi gula aren sebagai sumber sukrosa dapat meningkatkan nilai organoleptik terhadap rasa, warna dan aroma.

Variasi perlakuan gula pasir : gula aren (3:1) atau gula aren $25 \%$ dan penambahan penstabil CMC 1\% memberikan hasil optimal dengan kadar air 1,54\%, kadar abu $0,73 \%$, kadar gula $76 \%$, total padatan terlarut $97,01 \%$, total asam $0,16 \%$, serta. organoleptik terhadap aroma, warna, rasa dan kelarutan masing masing 3,08; 3,33; 3,$17 ; 3,33$ (disukai). Kandungan aktif terhadap 6,8,10 gingerol dan 6 shogaol, yaitu $1,240 \mathrm{mg} / \mathrm{g} ; 0,045 \mathrm{mg} / \mathrm{g} ; 0,070 \mathrm{mg} / \mathrm{g}$; $0,075 \mathrm{mg} / \mathrm{g}$.

\section{UCAPAN TERIMA KASIH}

Ucapan terima kasih kepada Elya Rovina yang telah membantu dalam pelaksanaan penelitian.

\section{DAFTAR PUSTAKA.}

Abdussamad, Z., 2014. Peningkatan mutu produk olahan pengrajin gula aren desa mongiilo, in: Prosiding. pp. 118122.

Bustan, M.D., Febriyani, R., Pakpahan, H., 2008. Pengaruh waktu ekstraksi dan ukuran partikel terhadap berat oleoresin jahe yang diperoleh dalam berbagai jumlah pelarut organik (methanol). J. Tek. Kim. No. 4, Vol. 15, Desember 2008 15, 16-26.

Chrubasik, S., M.H.Pitler, Roufogalis, B.D., 2005. Zingiberis rhizome: Comprehensive review on the ginger effect and efficacy profiles. Phytomedine, Int. J. Phyther. Phytopharm. 12, 684-701.

Embuscado, M.E., 2015. Spices and herbs: Natural sources of antioxidants - A mini review. J. Funct. Foods. doi:10.1016/j.jff.2015.03.005

Encik Eko, R., Martanto, 2016. Minuman fungsional serbuk instan jahe (zingiber officinale rosc) dengan variasi penambahan ekstrak bawang mekah (Eleutherine americana Merr) sebagai pewarna alami. J. Tek. Pertan. Lampung 4, 315-324.

Firdausni, F., Diza, Y.H., Failisnur, F., 2011. Potensi pigmen cassiavera pada minuman jahe instan sebagai minuman fungsional. J. Litbang Ind. 1, 15-21. doi:http://dx.doi.org/10.24960 /jli.v1i1.590.15-21

Ibrahim, A.M., Sriherfyna, F.H., Yunianta, 2015. Pengaruh suhu dan lama waktu ekstraksi terhadap sifat kimia dan fisik pada pembuatan minuman sari jahe merah (Zingiber officinal var. Rubrum) dengan kombinasi penambahan madu sebagai pemanis. J. Pangan dan Agroindustri 3, 530-541. 
Ismawati, N., Nurwantoro, N., Pramono, Y.B., 2016. Nilai $\mathrm{pH}$, total padatan terlarut, dan sifat sensoris yoghurt dengan Penambahan ekstrak bit (Beta vulgaris L.). J. Apl. Teknol. Pangan 5, 89-93.

Kamal, N., 2010. Pengaruh bahan aditif cmc (Carboxyl Methyl Cellulose) terhadap beberapa parameter pada larutan sukrosa. J. Teknol. I, 78-85.

Khan, R.S., Grigor, J., Winger, R., Win, A., 2013. Functional food product development - Opportunities and challenges for food manufacturers. Trends Food Sci. Technol. 30, 27-37. doi:10.1016/j.tifs.2012.11.004

Permata, D.A., Sayuti, K., 2016. Pembuatan Minuman Serbuk Instan Dari Berbagai Bagian Tanaman Meniran (Phyllanthus niruri). J. Teknol. Pertan. Andalas 20, 44-49.

Shobana, S., Akhilender Naidu, K., 2000. Antioxidant activity of selected Indian spices. Prostaglandins, Leukot.
Essent. Fat. Acids 62, 107-110. doi:10.1054/plef.1999.0128

Srinivasan, K., 2017. Ginger rhizomes (Zingiber officinale): A spice with multiple health beneficial potentials. PharmaNutrition.

doi:10.1016/j.phanu.2017.01.001

Stoilova, I., Krastanov, A., Stoyanova, A., Denev, P., Gargova, S., 2007. Antioxidant activity of a ginger extract (Zingiber officinale). Food Chem. 102, 764-770. doi:10.1016/j.foodchem. 2006.06.023

Zick, S.M., Djuric, Z., Ruffin, M.T., Litzinger, A.J., Normolle, D.P., Alrawi, S., Feng, M.R., Brenner, D.E., 2008. Pharmacokinetics of 6-gingerol, 8gingerol, 10-gingerol, and 6-shogaol and conjugate metabolites in healthyhuman subjects. Cancer Epidemiol. Biomarkers Prev. 17, 19301936. doi:10.1158/1055-9965.EPI-072934 